\title{
Hepatocyte Nuclear Factor 1-Alpha- Associated Monogenic Diabetes
}

National Cancer Institute

\section{Source}

National Cancer Institute. Hepatocyte Nuclear Factor 1-Alpha-Associated Monogenic

Diabetes. NCl Thesaurus. Code C129742.

Monogenic diabetes caused by inactivating mutation(s) in the gene HNF1A, encoding hepatocyte nuclear factor 1-alpha. 